\title{
Pengujian Kebocoran Apron Tahun 2019
}

\author{
Oktavia Puspita Sari ${ }^{1}$, Dila Nelvo Dasril ${ }^{2}$, Chairun Nisa $^{3}$, Almaiza $^{4}$ \\ 1234 Universitas Baiturrahmah Padang, Indonesia
}

Corresponding author: Oktavia Puspita Sari

E-mail: oktaviapuspitasari@atro.unbrah.ac.id

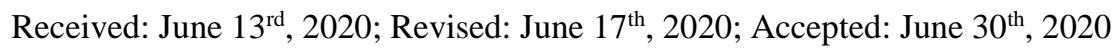

\begin{abstract}
Background: Based on observations made by researchers found incorrect apron storage. According to Permenkes No. 1250 of 2009, storage and placement of $\mathrm{Pb}$ aprons may not be folded and may not be hung. The purpose of this study is to determine whether or not there are leaks in the apron.

Method: Types of quantitative research approaches with experimental approaches. This research was conducted at the radiology installation. The testing is done by giving x-ray exposures on the surface of the apron. Based on the results of the exposure, the extent of the leak is in the apron. The measurement results will be compared with the theory Lambert 2001.

Results: According to Lambert, apron leakage is still acceptable if the critical area is less than $15 \mathrm{~mm}^{2}$ and if the non-critical area is less than $670 \mathrm{~mm}^{2}$. The results showed that of the 15 aprons studied three aprons leaked, namely apron 4, apron 7, and apron 13 with each leakage area being $562.84 \mathrm{~mm}^{2}, 312,174 \mathrm{~mm}^{2}$, $14,304 \mathrm{~mm}^{2} 71,818 \mathrm{~mm}^{2}$.

Conclusion: The total number of tested was 15 aprons, 3 aprons leaked and there was 1 apron which had no leakage. Leakage is caused by often placing an apron on the back of a chair, hanging an apron on a hanger, dropping an apron on the floor, and folding an apron on an examination table. Apron storage should be placed on a special rack in a horizontal position so as not to cause indentations or fractures on the lead.
\end{abstract}

Keywords: Apron; Apron storage.

\section{Pendahuluan}

APD adalah suatu alat yang mempunyai kemampuan untuk melindungi seseorang yang fungsinya mengisolasi sebagian atau seluruh tubuh dari potensi bahaya di tempat kerja(TRANSMIGRASI, 2010), APD yang biasa digunakan oleh pekerja radiasi adalah lead apron(Akhadi, 2000). Lead apron adalah celemek timbal yang dirancang untuk melindungi tubuh dari bahaya radiasi (Yulihendra, 2002).

Menurut Peraturan Kepala Bapeten No 8 Tahun 2011, bahwa setiap penyelenggara pelayanan harus memiliki alat proteksi radiasi yang memenuhi standart sesuai ketentuan yang berlaku (Nuklir, 2011). Berdasarkan ketentuan tersebut ketebalan minimal apron pelindung harus setara dengan $0,25 \mathrm{~mm} \mathrm{~Pb}$ dan ukurannya harus memberikan perlindungan yang cukup pada bagian badan dan gonad pemakai dari radiasi langsung.
Ketebalan ini efektif untuk menahan radiasi pada $100 \mathrm{kV}$ (Kartikasari et al., 2011, 2015).

Penyimpanan atau peletakan apron $\mathrm{Pb}$ jangan dilipat dan jangan digantung, karena dapat menyebabkan kerusakan yang akan mengurangi fungsinya sebagai peralatan proteksi radiasi (Kesehatan, 2009; Yudhi, 2008). Observasi yang dilakukan pada Bulan November 2018 masih di jumpai penyimpanan dan peletakan apron yang salah. Contohnya dengan meletakkan apron di atas punggung kursi (ruangan IGD), menggantungkan apron di hanger (ruang CT-Scan), menjatuhkan apron di lantai (CT-Scan) dan melipat apron di atas meja pemeriksaan (ruang IGD). Berdasarkan hasil observasi, dengan permasalahan yang terjadi di rumah sakit tersebut, maka peneliti tertatik melakukan penelitian lebih lanjut mengenai uji kebocoran apron tahun 2019. 


\section{Metode}

Jenis penelitian yang digunakan dalam karya tulis ilmiah ini adalah penelitian kuantitatif dengan metode eksperimen. Penelitian dilakukan di Instalasi Radiologi pada bulan Maret - bulan Mei 2019. Populasi dalam penelitian ini adalah seluruh apron yang ada berjumlah 15 apron. Pengambilan sampel dalam penelitian ini adalah dengan teknik Non probability sampling yaitu menggunakan sampel jenuh. Menurut Martono (2010), sampel jenuh merupakan teknik penentuan sampel bila semua anggota populasi dipilih sebagai sampel. Teknik ini disebut juga teknik sensus. Sehingga di dapatkan sampel dalam penelitian ini adalah 15 sampel. Metode pengambilan data menggunakan Studi Kepustakaan, Observasi, Dokumentasi. Prosedur penelitiannya adalah:

a. Sediakan 15 apron yang akan diteliti. Beri kode pada setiap apron. Misalnya, apron 1 diberi kode $A_{1}$.

b. Bagi bagian depan apron menjadi 3 bidang yaitu bidang $\mathrm{A}$, bidang $\mathrm{B}$, dan bidang $\mathrm{C}$.

c. Bagi bagian belakang apron menjadi 3 bidang yaitu bidang $\mathrm{D}$, bidang $\mathrm{E}$, dan bidang $\mathrm{F}$.

d. Periksa bagian depan dan bagian belakang apron secara teliti dari kekusutan dan ketidakrataan atau yang mengalami kerusakan.

e. Beri tanda pada bagian yang rusak menggunakan marker atau kawat.

f. Atur FFD $100 \mathrm{~cm}$, arah sinar vertikal tegak lurus menuju apron, dan ukuran kaset 24×30 $\mathrm{cm}$.

g. Faktor eksposi : $60 \mathrm{kV}, 10 \mathrm{mAs}$.

h. Ekspose apron pada bidang-bidang yang sudah ditentukan.

i. Setelah di ekspose, proses film untuk mengetahui ada atau tidaknya kebocoran apron. Apron yang bocor akan berwarna hitam pada film.

j. Ukur kebocoran pada film menggunakan jangka sorong untuk mendapat luas kebocoran.

k. Catat hasil pengukuran dalam bentuk tabel.

1. Bandingkan hasil pengukuran dengan teori Lambert \& McKeon (2001). Menurut Lambert \& McKeon (2001) Kebocoran pada daerah sensitif (gonad) tidak boleh melebihi $15 \mathrm{~mm}^{2}$ dan kebocoran pada daerah Non sensitif tidak boleh melebihi $670 \mathrm{~mm}^{2}$.

$\mathrm{m}$. Tarik kesimpulam dari hasil perbandingan.

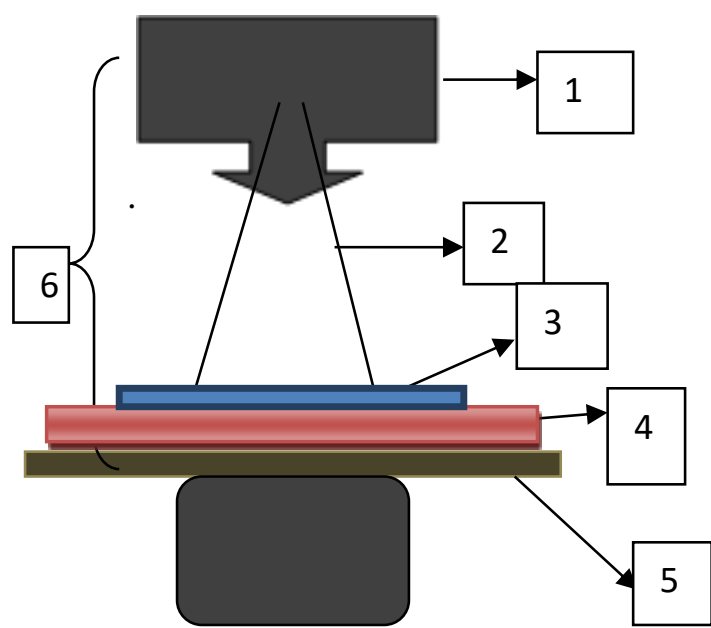

Gambar 1. Ilustrasi Pengujian Lead Apron Keterangan gambar:

1. Tabung pesawat sinar-X

2. Arah sinar-X tegak lurus

3. Lead Apron

4. kaset

5. Meja pemeriksaan

6. FFD 100

\section{Hasil dan Pembahasan}

Dari 15 apron yang diteliti, didapatkan hasil gambaran radiografi pada apron yang mengalami kebocoran setelah diproses sebagai berikut.

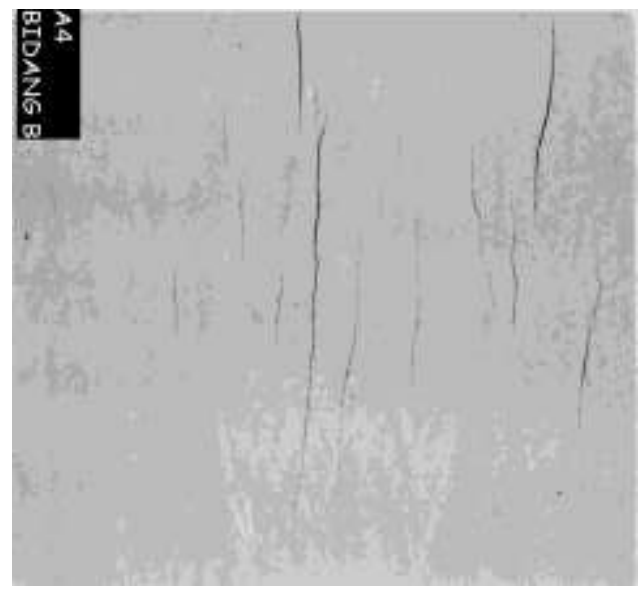

Gambar 1. hasil ekspos $\mathrm{A}_{4}$ bidang B

Ilustrasi pengujian : 


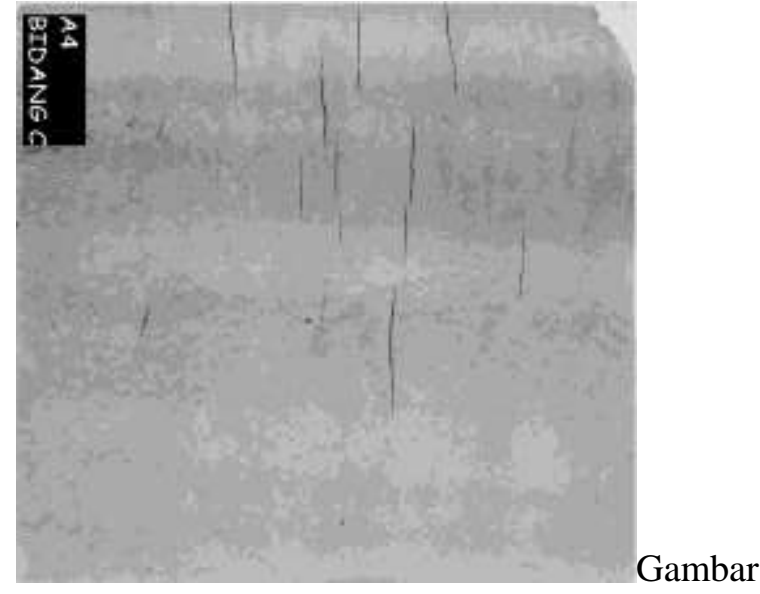

2. hasil ekspos $\mathrm{A}_{4}$ bidang $\mathrm{C}$

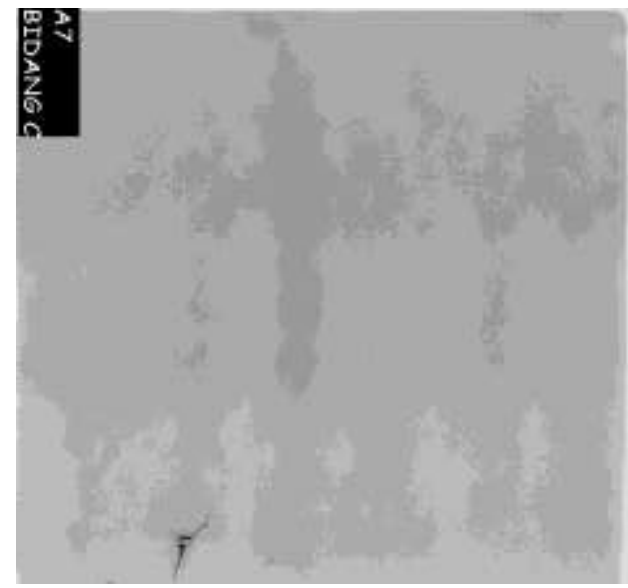

Gambar 3. hasil ekspos $\mathrm{A}_{7}$ bidang $\mathrm{F}$

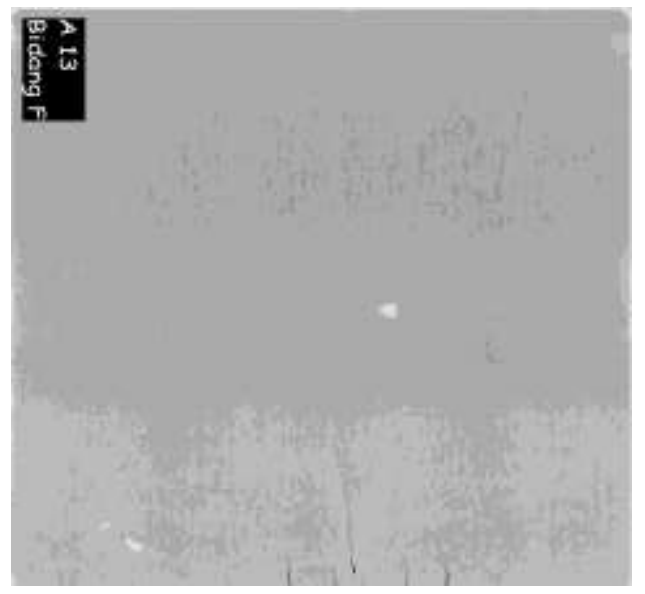

Gambar 4. hasil ekspos $\mathrm{A}_{13}$ bidang $\mathrm{F}$

Berdasarkan hasil pengukuran 15 apron yang diteliti di RSUP. Dr. M. Djamil Padang terdapat 3 apron yang mengalami kebocoran yaitu apron 4, apron 7, dan apron 13 mengalami kebocoran. Dimana luas kebocoran apron 4 pada bidang B adalah $562,84 \mathrm{~mm}^{2}$ dan luas kebocoran pada bidang $C$ adalah $312,174 \mathrm{~mm}^{2}$. kemudian luas kebocoran apron 7 pada bidang $\mathrm{C}$ adalah 14,304 $\mathrm{mm}^{2}$. Selanjutnya luas kebocoran apron 13 pada bidang $\mathrm{F}$ adalah $71,818 \mathrm{~mm}^{2}$. Kebocoran apron 4 pada bidang $\mathrm{B}$ tidak melebihi teori, namun pada bidang $\mathrm{C}$ sudah melebihi teori. Kemudian untuk kebocoran apron 7 pada bidang $\mathrm{C}$ tidak melebihi teori. Selanjutnya luas kebocoran apron 13 pada bidang $\mathrm{F}$ tidak melebihi teori . Berdasarkan teori (Lambert \& McKeon, 2001) kebocoran masih bisa diterima jika pada daerah kritis kurang dari $15 \mathrm{~mm}^{2}$ dan jika pada daerah non kritis kurang dari 670 $\mathrm{mm}^{2}$.

Penyebab terjadinya kebocoran apron diantaranya disebabkan penyimpanan dan peletakan apron yang salah. Berdasarkan hasil observasi, seringkali dijumpai seperti meletakkan apron di atas punggung kursi, menggantungkan apron di hanger, menjatuhkan apron di lantai, dan melipat apron di atas meja pemeriksaan. Jika dilihat dari segi usia apron juga mempengaruhi terjadinya kebocoran, karena semakin lama usia apron maka semakin lama juga waktu pemakaian apron tersebut. Sehingga timbalnya juga akan mengalami kerusakan.

\section{Simpulan}

Berdasarkan hasil penelitian yang dilakukan, maka dapat ditarik kesimpulan sebagai berikut:

1. Dari 15 apron yang diteliti, ada 3 apron yang mengalami kebocoran, yaitu apron 4, apron 7 dan apron 13.

2. Kebocoran apron 4 terletak pada bidang B dengan luas kebocoran $562,84 \mathrm{~mm}^{2}$ dan bidang $\mathrm{C}$ dengan luas kebocoran $312,174 \mathrm{~mm}^{2}$. Luas kebocoran pada bidang B tidak melebihi teori sedangkan pada bidang $\mathrm{C}$ sudah melebihi teori dan harus diganti. Kebocoran apron 7 terletak pada bidang $\mathrm{C}$ dengan luas kebocoran $14,304 \mathrm{~mm}^{2}$ dan tidak melebihi teori sehingga tidak perlu diganti. Selanjutnya luas kebocoran apron 13 pada bidang $\mathrm{F}$ tidak melebihi teori sehingga masih aman untuk digunakan dan tidak perlu diganti.

3. Kondisi 15 apron dari fisik masih bagus kecuali apron yang terletak di ruang IGD yaitu $\mathrm{A}_{4}$ karena sudah mengalami robekan pada bagian bahu.

4. Jumlah apron yang berfungsi dengan baik adalah 14 apron.

5. Seharusnya Penyimpanan atau peletakan apron $\mathrm{Pb}$ jangan dilipat dan jangan digantung, karena dapat menyebabkan kerusakan yang akan mengurangi fungsinya sebagai peralatan proteksi radiasi. 


\section{Daftar Pustaka}

Akhadi, M. (2000). Dasar-Dasar Proteksi Radiasi. Rineka Cipta.

Kartikasari, Y., Darmini, \& Rochmayanti, D. (2015). Evaluasi Kecukupan Tebal Lead Apron Guna Mendukung Jaminan Keselamatan Radiasi pada Unit Pelayanan Radiologi Rumah Sakit. Link, 11(2).

Kartikasari, Y., Masrochah, S., \& Wibowo, A. S. (2011). Efektivitas Performance Lead Apron sebagai Salah Satu Alat Proteksi Diri terhadap Bahaya Radiasi di Instalasi Radiologi Rumah Sakir di Kota Semarang.

Kesehatan, P. M. (2009). Permenkes Nomor 1250/MENKES/SK/XII/2009 tentang Pedoman Kendali Mutu (Quality Control) Peralatan Radiodiagnostik.

Lambert, K., \& McKeon, T. (2001). Inspection of Lead Aprons : Criteria for Rejection. Health Physics, 80, S67-S69. https://doi.org/10.1097/00004032200105001-00008

Martono, N. (2010). Metode Penelitian Kuantitatif: Analisis Isi dan Analisis Data Sekunder. Rajawali Press.

Nuklir, B. P. T. (2011). PERKA BAPETEN No. 8 Tahun 2011 tentang Keselamatan Radiasi Dalam Penggunaan Pesawat Sinar-X Radiologi Diagnostik dan Intervensional.

TRANSMIGRASI, P. M. T. K. D. (2010). Permenakertrans Nomor PER.08/MEN/VII/2010 tentang Alat Pelindung Diri.

Yudhi. (2008). Proteksi Radiasi. www.infonuklir.com

Yulihendra. (2002). Alat Proteksi Diri. igilib.unimus.ac.id/download.php?id=5723 